\title{
Ode to the Unknown Mentor
}

\author{
Arthur M. Michalek ${ }^{1}$
}

Published online: 14 July 2017

(C) American Association for Cancer Education 2017

Over the past month or two, I have been debating the topic of this editorial. I was tempted to continue on the theme of my last editorial and focus on US federal policy affecting health services and research, but I thought you might get the right impression that I am becoming a bit cranky with the current leadership vacuum in Washington. I then began ruminating about a topic always at the forethought of educators, and that is, the role of mentor, but perhaps not in the traditional sense. According to Merriam Webster", a mentor is "a friend of Odysseus entrusted with the education of Odysseus' son Telemachus; a trusted counselor or guide." Most of us immediately think of some senior faculty member who guided us through our graduate or postgraduate studies. Some individual who infused within us the knowledge, skills, and professionalism that made us who we are today. You and I could most certainly waxed poetic about those individuals who were most critical to our professional development. This was to be the topic of my editorial until Memorial Day when I began to reflect upon other teachers and life lessons learned. Memorial Day in the USA is viewed as the unofficial start of the summer, but more importantly, it is a day set aside in memory of those who lost their lives in defense of the freedoms that we enjoy. This day brings to mind the true price of freedom. I learned what the cost of the freedom and the cost of war truly is an early September morning in 1968 when I learned that my freshman math teacher (Second Lieutenant Melvin Owczarczak) had died after stepping on a land mine in Vietnam. He was, through my freshman eyes, a gifted teacher and a wonderful person. I firmly decided upon the

Arthur M. Michalek

amm3@buffalo.edu

1 University at Buffalo, Buffalo, NY, USA topic for this editorial several weeks ago when I read an interview given by a colleague of mine (Dr. Norma NowakUniversity at Buffalo) who, when asked, was the most influential in her career answered that it was her grandmother. She confirmed for me the fact that some of our greatest mentors are not those individuals who directly nurtured us in our profession, but taught us other life lessons. This, coupled with the fact that my wife and I have attended approximately 16 funerals in the past 18 months, unleashed a stream of consciousness of the lessons I learned from those most recently deceased. Being a good Catholic, I view death somewhat morosely. I was taught that if we led a moral life that we would all meet up again and "live" joyously in the presence of the Lord. We Catholics also mourn the dead. Several years ago, a Baptist colleague of mine passed on and his funeral was anything but somber. They shouted with joy in the celebration of his life. They recounted the impact he had on the lives of others. The influence he had on the lives of so many was truly astounding and no mention was made of his influence on their professional development. Yet, he appeared to have been a great teacher without ever knowing that he was. I cannot be thinking of the individuals I mourned this past year when I should have been celebrating the lessons that they taught me and many others. I will not recount them all nor expound upon their virtues and influence. I will, however, remark on a few and ask that you think back on all those who have had a similar effect on you. Celebrate the lives of the deceased and take an opportunity to thank those who are still alive.

I lost a number of great teachers these past 18 months. They range from true mentors like Dr. Edwin Mirand who taught me the merits of higher education administration and how to survive. Dr. Sid Saltzstein, a true gentleman and past president of the AACE and a mentor to many, who taught us the value of passion, humor, and hard work. Dr. Anne Lanier, frequent participant at our annual meeting and the most eminent 
advocate of cancer education and epidemiology in the state of Alaska, who taught us that one person can make a difference. She was famous for developing networks of like-minded individuals to tackle common problems and moving Alaska Natives to healthier lives.

There were also many other less professionally prominent individuals who played equally great roles as teachers throughout their own lives. I am quick to remember my son-in-law's father (Mathias Becker) who was always so generous of his time, talents, and treasures (an accomplished plumber who never laughed at my silly attempts at plumbing). My wife's uncle (James Moeller) who taught us the courage it takes to fight a losing battle with cancer. A compassionate young man (Ron Guard) who taught me that heart disease is still the number 1 killer in America and often strikes suddenly and without warning. My cousin's father-in-law (Santo Bueme) who demonstrated that life goes on even after losing his precious wife and battling the infirmities of old age. My cousin (John Curran) who taught me courage through his lifelong battle with epilepsy and other developmental issues who always had a smile and a good word no matter how harsh the circumstances.
Another young lad, who will remain nameless, who showed us the cost of drug use after dying from a heroin overdose. Another young lad (again nameless) taught us the costs of not speaking openly of depression and, unfortunately, left this world on his own terms and the rest of us trying to make sense of such a tragic loss. Not all lessons are good lessons, but we learn from them all or at least we should.

Take some time to think of your true teachers and the valuable lessons that they have shared. Finally, commencing with the next issue I hope to introduce a new section entitled "Conversations with a Mentor." This column will identify and interview accomplished mentors within our Association so that they may share the lessons they have learned in their careers to the benefit of all. So, if you know of some special mentor within the Association, please send me an email.

I hope to see you all in September at the meetings in Cleveland. Be well.

Arthur M. Michalek, PhD, FACE.

1. Definition of Mentor. Www.merriam-webster.com/ dictionary/mentor 